\title{
Thoughts on Ceramic Culture Education in the Second Class of Jingdezhen Colleges
}

\author{
Hui $\mathrm{Li}^{1, \mathrm{a}}$, Dong Cheng ${ }^{1, \mathrm{~b}}$, Jie Gao ${ }^{1, \mathrm{c}}$ and Shun $\mathrm{Xu}^{1}$ \\ ${ }^{1}$ College of Science and Art, Jingdezhen Ceramic University \\ 710309089@qq.com,531070948@qq.com,705415684@qq.com
}

Keywords: Jingdezhen colleges; Second class; Ceramic culture education

\begin{abstract}
Ceramic culture is an excellent traditional culture of China, and increasing importance has been attached to ceramic cultural education. There are five colleges characterized by ceramic located in Jingdezhen city, which is honored as "home of porcelain for thousands of years". Taking Jingdezhen Ceramic Institute as an example, this paper discusses the current ceramic culture, education situation in the second class of Jingdezhen colleges, as well as the problems and profound consideration, which may provide theoretical guidance for ceramic culture education in the second classroom activities and ceramic culture universal education for colleges.
\end{abstract}

\section{Introduction}

In the report of the 19th national congress of the communist party of China (CPC), General Secretary $\mathrm{Xi}$ Jinping pointed out that we should uphold cultural confidence and promote the prosperity of socialist culture. In the general office of the state council issued "on the opinion of Chinese excellent traditional culture inheritance development project's implementation" pointed out that we hope to take excellent traditional culture as a grasp, build a powerful socialist cultural power and enhance the national culture. In this year's two sessions, the voice of traditional culture in the campus is unceasing, excellent traditional culture in the campus has become the education development trend. Ceramic culture, as an important part of China's excellent traditional culture, has a strong cultural discourse power. In Jingdezhen colleges featured by ceramic, the ceramic culture and education work should not only be incorporated into the teaching of ceramics majors, but also should add more element of a ceramic culture in the second class of colleges, which made the ceramic culture alive by conducting characteristic ceramic cultural education activities of the second class. Moreover, it also creates a good atmosphere of bringing ceramic culture to people, which made the ceramic culture from the "niche" to "mass."

\section{Jingdezhen Ceramic Culture and the Second Class Education of Colleges}

Jingdezhen, as home of porcelain for thousands of years, contains rich ceramic cultural resources. Jingdezhen's ceramic materials and cultural resources are handicraft cultural resources related to ceramic production in the Jingdezhen millennium, including ceramic historical and cultural blocks, area village, scenic areas, historical and cultural villages, famous towns, and modern and contemporary ceramic industrial heritage. There are living fossils of Jingdezhen ceramic material culture, such as Galen, Yao Li, ancient kiln, hutian ancient kiln site, sculpture porcelain factory, to xichuan, etc. . There are also a lot of intangible cultural resources, which provide a unique witness for civilization or cultural traditions has faded over one thousand years, including folk literature, folk music, traditional craftsmanship, folk art, folk custom, etc. Jingdezhen colleges can make full use of Jingdezhen's ceramic cultural resources to carry out students' ceramic culture education activities of the second class.

Taking Jingdezhen Ceramic Institute (JCI) as an example. JCI set up the second class teaching and research section in 2014, introduced a series of policies such as the second class education project evaluation method. JCI supports for the innovating practice that combines the first class education with the second class education, which made the second classroom become the powerful supplement of the first class. There are many second classroom activities about the 
ceramic culture education, such as ceramic apparel performance, youth behavior art show, art campus tour etc.. As the second classroom education is open, universal and flexible in ceramic culture, the students' passion of learning ceramic culture and comprehensive quality has been improved greatly by carrying out the creative practice education activities about ceramic education and art.

\section{The Problem of the Education of the Ceramic in Jindezhen's Colleges and Universities's Second Classes.}

Pay more attention to professional education, and pay less attention to the activities of the education of the culture of the ceramic in Jingdezhen's colleges and universities's second class.Jingdezhen's colleges and universities are very serious about the professional education in the aspect of ceramic,not only the payment in the places for experiment and training,but also the teacher.Compare with the talents who learn ceramic,the others colleges and universities didn't set up the places for the second class's education of the culture of ceramic, which face to the students, and they have no professional teachers,neither.All of the resources of the education of the culture of ceramic just used for the students who learn it,which leads to the result that the activeties of the education of the culture of ceramic in second classes has no continuity,but can only stop in the suffer of it.

The education of the culture of the ceramic in Jingdezhen's colleges and universities's second classes are not suitable for most part of people. On the one hand, the organization in activities of the second class's education of the culture of ceramic are mainly for the students who learn the arts, so it doesn't suit for everyone, and doesn't have enough attractions for the students who don't learn ceramic that they are hard to fit in and don't actively enough to take part in. The organization of the activities is serious enough, which

On the other hand, because there are no career planning of "the great ceramic"in the education of those who don't learn about ceramic in colleges. The campus recruitment in Jingdezhen's colleges and universities are paying more attention to the profession of ceramic, except for the professions which are related to ceramic, there are also the recruitments for the job in management, production and sell, etc.. There will be the student's advantages when they are searching for a job if they have the reservation of the knowledge about the culture of ceramic.

Didn't turn the resources of the education of Jingdezhen's culture of ceramic to advantages well enough,Jingdezhen has a large amount of resources about the culture of ceramic. Depend on the resources, the activities of the second class can be well carried out,and give play to the function of education of the social culture of ceramic .And improve the connotation of the activities of the second class at present by blending in the culture of Jingdezhen's ceramic,create more brand activities of the second classes which about ceramic.But actually, in concrete jobs, there are always have the problem,such as the lack of communication between the colleges and universities, and the related department in cities, the wrong information, and the incomplete pass,etc.

\section{The Reflection of the Extracurricular Classes of Ceramics Culture Education Activities in Jingdezhen Colleges}

According to the content of the activities, there are three main aspects. The first part is starting the practical activity of the extracurricular classes, such as visiting ceramics cultural resources, the volunteering activities of ceramics culture, the researches of traditional street history, the inheriting activities of ceramics intangible culture. Second, starting the extracurricular session of ceramics educational activities are meaningful and important to improving the literary accomplishment of university students. Also, holding competitions of ceramics knowledge, performing shows regarding ceramics culture and conducting situation practice can improve the students' interest of ceramics culture. Moreover, the publicity of ceramics culture through the campus new media can make the students have the awareness of national spirit, including the professional ethics and craftsmanship spirit and can improve the ideological quality of students. The third aspect is starting 
the education of innovation and entrepreneurship in the ceramics area. Recently, most of the innovative programs for the university students are related to ceramic art, therefore, starting the extracurricular session of ceramics innovation activity is necessary. For example, some art students can take part in the art studio activity in the extracurricular session.

As for the form of the activities, firstly, the universities are supposed to enhance the planning and guiding of the extracurricular classes and to organize high-level academic activities with the guidance of the topic and content of the activities. In addition, the reasonable and helpful support from universities to brand activities is necessary as well. Secondly, the students' autonomous learning ability towards ceramics culture should be improved by enhancing the establishment of ceramics culture club. Thirdly, the student union should play an important role in the extracurricular class activity using the leadership of the student union. To be more specific, the education of ceramics culture should be a main purpose of all the activities and activity management. Furthermore, the independent learning atmosphere needs to be formed by the students' subjective initiative. Eventually, the independent educational function of extracurricular class will be achieved by above elements.

\section{The Significance of Education Activity of Ceramic Culture in the Second Class of Jingdezhen University}

From the perspective of students. The students' ability of thinking, quality and skills can be improved. Ideological level: Make students realize the extensive and profound ceramic culture and spiritual connotation of Jingdezhen, improve their national pride, enhance their cultural and national confidence. Make the second class activity more cultural. Quality level: ceramic culture through the second classroom vivid contents, lively activity form is easier to make the students accept and make students' humanity's quality, professional and comprehensive quality continuously improve in the activity. Skill level: Through the second class ceramic handicraft workshop, students of ceramic art can further improve their professional skills and innovative entrepreneurial skills.

From the perspective of the school. Students' ideological and political education in colleges and universities and the development requirements of the teaching reform help to cultivate interdisciplinary talents in universities, and they're helpful for constructing featured brand in the second classroom activities and social practice base of the second classroom.

From a social perspective. It can improve the popularity of Jingdezhen ceramic culture, education, inheriting and development of Jingdezhen ceramics in one thousand was set up good image, promote greater development and prosperity of socialist culture. It is conducive to creating a good ceramic culture atmosphere, inheriting and innovating Jingdezhen's ceramic culture, and giving full play to the social educational function of Jingdezhen's material and cultural resources.

\section{Conclusions}

Professor Ning Gang of Jingdezhen ceramic university raised the proposal of "implement ceramic culture, communication project" in the two sessions of this year, which attracted wide attention. Through the group of the university students make the excellent traditional culture of pottery and porcelain culture, heritage and development effectively, so as to achieve "Khalid ents, perfect the Chinese excellent traditional culture education" to deepen the reform goal of the education field. Jingdezhen university should make full use of the rich Jingdezhen ceramic culture resources to build the brand second class ceramic culture education activity. Make full use of the second class activity of ceramic culture theme education, on the one hand, seek for more updated and more effective carriers for the effective development of the second class activity; On the other hand, enrich the forms of the second classroom activity and content.Both can please come in and go out, make the second classroom become more interesting,entertaining,informative, autonomy and practice activities, improve the weakness of the first class education, improve education effection, the effective complement to become the first class which can create the atmosphere of campus culture with the characteristic of ceramic culture. Through the experience of the second classroom 
teaching, scene teaching, diverse students happy activities motivate students' interest in learning ceramic culture, guide students to the deeper understanding of the ethnic Chinese culture, take the essence, discard the dross, inherit excellent ceramic culture essence.

\section{Acknowledgements}

Fund: Jiangxi university humanities and social sciences research 2017 project "Jingdezhen ceramic culture integration, college students second class activity study" (project no. : YS17226)

\section{References}

[1] Chen Yukon, Yang Liza. Discussion on the concept and characteristics of ceramic culture [J]. Journal of Nanjing art college, 2010.4.

[2] NingGang. Chinese ceramic art from the perspective of "One Belt And One Road" [J]. Journal of ceramics, 2017.5

[3]Anmei Chen, zhang weiguo. Analysis of education in the second classroom of colleges and universities [J]. Education exploration 2016.5

[4] Wang Jing and Huang are shielding. Research on the construction of college students' second class under the background of "double innovation". Chinese adults education. 2017.14

[5] Shizhao N, Zheng W, Wangmo P, Yuan N, Peng L. Big Data Prediction of Durations for Online Collective Actions based on Peak's Timing [J]. Physica A: Statistical Mechanics and its Applications, 2018, 55: 130-139. 